\title{
DETERMINANTS OF SUSTAINABLE INNOVATION MANAGEMENT IN LARGE COMPANIES
}

\author{
[Klíčové faktory dlouhodobě udržitelného inovačního managementu \\ ve velkých společnostech]
}

\author{
Andrea Cebáková ${ }^{1}$ \\ ${ }^{1}$ Brno University of Technology, Faculty of Business and Management, Kolejni 2906/4, 61200 Brno \\ Email:cebakova@fbm.vutbr.cz
}

\begin{abstract}
The paper aims to form a useful tool for evaluation of sustainable innovation process in large manufacturing company. Several studies proved positive correlation between innovation and increased performance of companies and since large companies have the advantage of wide-range activities which opens new possibilities to innovate, they became driving force in innovation field. The main determinants of successful innovation are established based on literature research and used to create a questionnaire for the purpose of the examination of innovation management in selected company. Research suggests that main determinants need to be managed jointly because it is not possible to separate completely one determinant from another. The synergetic effect of all determinants complying together is proven to be a cause of successful innovation.
\end{abstract}

Keywords: determinants, innovation, large business, management, organization.

JEL classification: M10, O31, O32, O39

Received: 1.10.2018; Reviewed: 21.10.2018; 6.2.2019; Accepted: 19.6.2019

\section{Introduction}

Innovation is fascination trend which forces people to be better and to look for new, different ways of doing things. The same is required from companies. They need to offer something original, unique or improved in order to attract customers, investors or employees. Innovation has become necessary for survival and constant growth of company. Well managed innovation process has a significant impact to success on innovation, but there is not universal concept of successful innovation. Every process of innovation must be adapted for the specific needs of each company. On the other hand, establishing critical determinants of that process should produce guidance for prosperity of innovation.

Innovation process is influenced by many determinants that differentiate in their strength, importance or position in the innovation process. Interdisciplinary approach is needed to outline all determinants and not even that is a guarantee of capturing of all of them. It is possible to distinguish few main factors which are universal for every company but for application of the innovation process, the specifics of each company must be taken to consideration (Klewitz and Hansen 2014). Innovation is strongly influenced by external determinants such a current political situation, legal requirements on company`s activities, environment existing outside the company or cultural background of the state where the company is doing its business (Romijn and Albaladejo 2002). Managers of company should be aware of particularity of innovation process and consider all determinants in their decisions. Innovation usually does not serve only as instrument for higher profitability of company but also for society as whole, since it should bring something new and useful for the future. 
The paper is divided into five parts starting with literature review where main trends are discussed, followed by methodology used in research and determinants of sustainable innovation. Results of research are included in next chapter continued by conclusion where summary of research is presented.

\section{Literature review}

One of the first remarks of innovation can be found in antic Greek philosophy made by Xenophon (474 $\mathrm{BC})$ : "And were it made clear that the discovery of some way of raising revenue without hurting anyone will also be rewarded, this field of research too would not be unoccupied. In a word, once it becomes clear in every department that any good suggestion will not go unrewarded, many will be encouraged by that knowledge to apply themselves to some promising form of investigation. And when there is a wide-spread interest in useful subjects, an increase of discovery and achievement is bound to come".

Various definitions of innovation can be found in the literature. Naturally innovation is associated with new or dramatically improved product, process or service. Current approach to innovation started with Schumpeter (1934) who defined innovation as " $a$ historic and irreversible change in the method of production of thing" and "creative destruction" (Schumpeter 1934, pp. 65). As newer definition Mueller and Thoring concept can be mentioned: "Innovation is a concept that depicts not only something that is new but also that is economically viable, technically feasible and expected to be successful in the market" (Mueller and Thoring 2012, pp. 153).

OECD recognized innovation as: "An innovation is the implementation of a new or significantly improved product (good or service), or process, a new marketing method, or a new organizational method in business practices, workplace organization or external relations" (OECD 2005, pp. 46). In the essence, every activity which a company undertakes can form something new which can be considered as innovation.

Peculiar ways of innovation can be found when comparing companies amongst themselves. Differences may result from national culture, regional culture, industry or type of company. In the comparison of large and small companies, size of the company influences the innovation. Small firms have the advantage of flexibility, efficiency, proximity to the market and motivation, large firms have the advantage of economies of scale and scope, financial and technological resources (Love and Roper 2015). Large firms usually have specialised innovation or research or development departments (Wong and Aspinwall 2004).

Boly et al. (2014) introduced fifteen fundamental innovation management best practises as: design, project management, integrated strategy, project portfolio management, suitable organization definition, innovation process improvement, competence management, moral support, knowledge management, competitive technology and intelligence activities, network management, collective learning, ideas research/creativity, RD activities, customer relationship management. Zien and Buckler (1997) introduced seven universal principles of innovative companies, stating the importance of relation between stakeholders. The main principles for building the innovative company are: shared vision, leadership, will to innovate, appropriate organization structure, key individuals, high involvement in innovation, effective team working, creative climate-positive approach and motivation systems (Tidd and Bessant 2009). Tang (1998) proposed a model of six determinants of innovation: information and communication, behaviour and integration, knowledge and skills, project raising and doing, guidance and support, and external environment. Importance of teamwork as essential feature 
of innovative project is recognized by Hoegl and Gemuenden (2001), also team composition as base of experience and competencies (Cooper 2000) and the capacity to exploit knowledge transfer between team members with different skills (Tiwana and McLean 2005). Teamwork can be helped by an open environment (Andriopoulos 2001), psychological safety (Kessel et al. 2012), shared vision and goals (Al-Beraidi and Rickards 2003), clear objectives for group work (Egan 2005) and a supportive learning culture (Thompson 2003). Diversity in teams has been found to be more creative, whereas homogeneous groups, whose members possess overlapping skills, are less likely to develop creative ideas. (Blomberg et al. 2017). The concept of knowledge management has been recognised by numerous authors as an important determinant of innovation (Yamin et al. 1999; Darroch and McNaughton 2002; Carneiro 2002).

\section{Methodology}

The research is made by using secondary research where the research articles were primarily management oriented because focus was made on innovation within organisations. Based on the secondary research the questionnaire was made. It contains "yes" and "no" answer to for simplicity and for user friendly use. The questions are deliberately formulated to represent good practices resulted from secondary research and knowledge of researcher. The desirable good practise is hidden under "yes" reply with few exemptions. The case study was designed to test the basics of the questionnaire which can be also later use for evaluation of company in innovation management and to identify its strength and weaknesses. The questionnaire can be used as accessible and effective tool for management with clear guidance to improvement.

\section{Determinants of sustainable innovation process}

Determinants were established by their occurrence and importance based on multiple researches summarized by Read (2000). It contains ten main determinants of successful innovation: management, customer/market focus, communication, human resources, teamwork, knowledge management, leadership, creativity, strategy, continuous improvement.

Figure 1: Synergetic effect of determinants of sustainable innovation

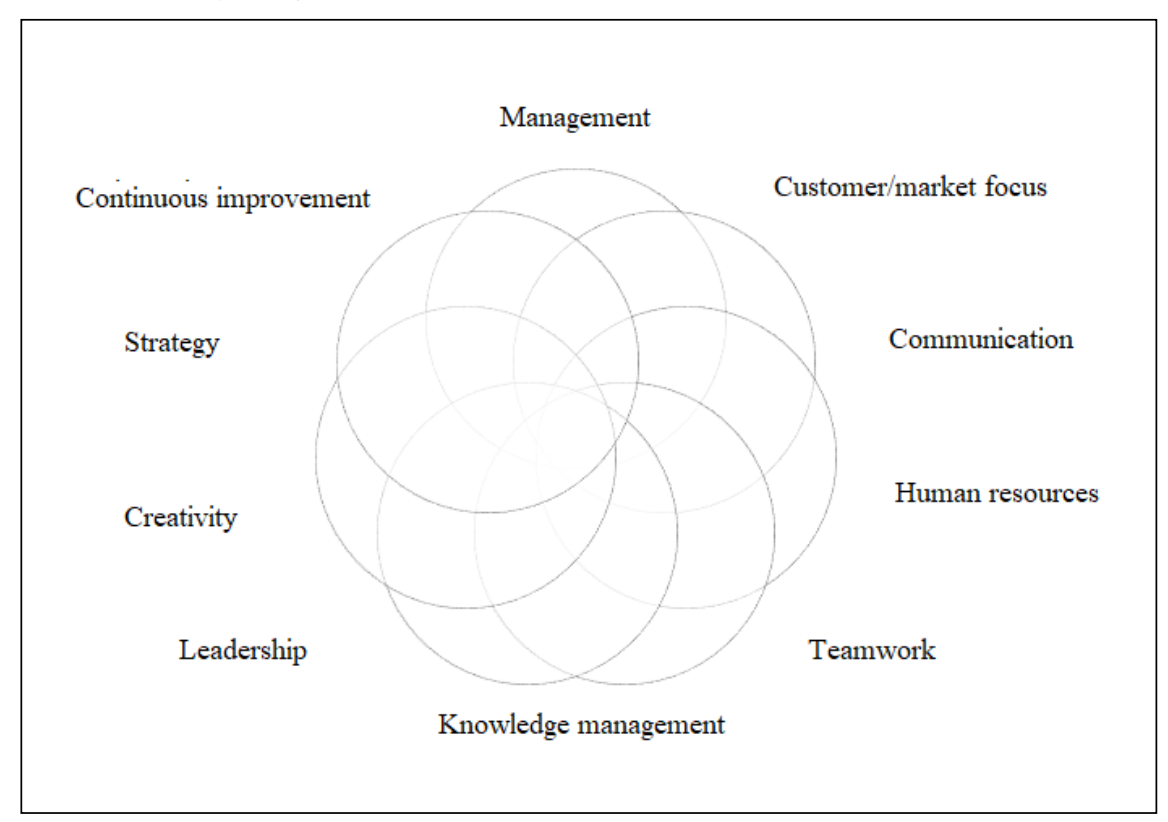

Source: own processing based on Read 2000 
It is essential that all determinants are overlapping between each other. The clear and precise separation of determinants it is possible but not recommendable. The synergy effect of determinants all together is the main reason for successful innovation.

The case study research was made in large Czech company which is part of international group where the level of operation management answered the questionnaire. The company operates as manufacturer and distributor of medical and hygienic products. The purpose of this case study research was to test the relevance of the question in selected company. The company was purposely chosen as successful innovation leader where successful innovation process is already in place. That way the questionnaire can be later used for less successful companies also as learning tool.

\subsection{Management}

Determinant called "management" is used in narrower sense and includes questions about vision, company`s structure, financial objectives or general approach to innovation activities.

Table 1: Management

\begin{tabular}{|c|c|c|}
\hline Question & Yes & No \\
\hline Do you have clearly stated vision? & $\mathrm{X}$ & \\
\hline Are your short-time plans based on the vision? & $\mathrm{X}$ & \\
\hline Is every employee aware of firm's vision? & & $\mathrm{X}$ \\
\hline Does every employee participate on forming firm's vision? & & $\mathrm{X}$ \\
\hline Is there specialised department focusing solely on innovation? & $\mathrm{X}$ & \\
\hline Is the firm open to proposal from the line management? & $\mathrm{X}$ & \\
\hline Are rules and procedures guiding the company activities written? & $\mathrm{X}$ & \\
\hline If yes, are they strict? & $\mathrm{X}$ & \\
\hline Does the firm's structure help to take decisions rapidly? & $\mathrm{X}$ & \\
\hline Is the firm structure flexible to innovation activities? & $\mathrm{X}$ & \\
\hline Do you clearly state time and financial objectives before starting the project? & $\mathrm{X}$ & \\
\hline Are time and financial objectives evaluated at the end of the project? & $\mathrm{X}$ & \\
\hline Are any innovation activities cancelled due the lack of financial resources? & $\mathrm{X}$ & \\
\hline If yes, what is the percentage of cancelled innovation? & 30 & \\
\hline Are any innovation activities cancelled due the lack of technical skills? & & $\mathrm{X}$ \\
\hline Are any innovation activities cancelled due the lack of human resources? & & $\mathrm{X}$ \\
\hline Is there top management commitment and support for innovation? & $\mathrm{X}$ & \\
\hline Is there different procedure for large and small innovation project? & $\mathrm{X}$ & \\
\hline Are employees encourage to make improvements in their work area? & $\mathrm{X}$ & \\
\hline Are there formal policies and procedures for improvements in employee work area? & $\mathrm{X}$ & \\
\hline
\end{tabular}

Source: own processing

\subsection{Customer/market focus}

Determinant called "customer/market focus" is used to examine the extent of interaction with customer and awareness of market trends. Source of new ideas is also introduced as part of the questionnaire. 
Table 2: Customer /market focus

\begin{tabular}{|l|c|c|}
\hline Question & Yes & No \\
\hline Do new ideas come from external sources (customers/markets)? & $\mathrm{X}$ & \\
\hline Do new ideas come from internal sources (employees, shareholders)? & $\mathrm{X}$ & \\
\hline Does the firm understand customer's needs? & $\mathrm{X}$ & \\
\hline Do you constantly search for feedback from customers? & $\mathrm{X}$ & \\
\hline Are you surprised by development in your sector/market? & & $\mathrm{X}$ \\
\hline Do you analyse current trends in markets? & $\mathrm{X}$ & \\
\hline Do you systematically compare your products with products of your competition? & $\mathrm{X}$ & \\
\hline $\begin{array}{l}\text { Do you work closely with local and national education system in order to communicate } \\
\text { your needs in human resources? }\end{array}$ & $\mathrm{X}$ & \\
\hline Do employees know what customers need and why is necessary to innovate? & $\mathrm{X}$ & \\
\hline
\end{tabular}

Source: own processing

\subsection{Communication}

Determinant called "communication" aims to examine external and internal communication of innovation. The extent of feedback is also introduced as part of questionnaire.

Table 3: Communication

\begin{tabular}{|c|c|c|}
\hline Question & Yes & No \\
\hline Do you collaborate with external partners during innovation activities? & $\mathrm{X}$ & \\
\hline Is the feedback from customers communicated to everyone? & & $\mathrm{X}$ \\
\hline Are there any measurements of project progress? & $\mathrm{X}$ & \\
\hline Are there any standards for frequency of meeting regarding innovation projects? & $\mathrm{X}$ & \\
\hline Is innovation project communicated formally? & $\mathrm{X}$ & \\
\hline Is innovation project communicated informally? & $\mathrm{X}$ & \\
\hline Do use newsletters, bulletins, displays, boards to communicate the innovation activities? & $\mathrm{X}$ & \\
\hline If yes: Can every employee contribute to them? & $\mathrm{X}$ & \\
\hline Do you regularly review effectivity of your communication channels? & & $\mathrm{X}$ \\
\hline
\end{tabular}

Source: own processing

\subsection{Human resources}

Determinant called "human resources" weigh up the hiring process in the company and to examine employee relations activities. Aspect of creativity of employee is introduced as part of questionnaire.

Table 4: Human resources

\begin{tabular}{|l|c|c|}
\hline Question & Yes & No \\
\hline Is the level of creativity questioned when hiring a new employee? & & $\mathrm{X}$ \\
\hline Are motivation factors of each employee examined? & $\mathrm{X}$ & \\
\hline Is employee motivation monitored? & $\mathrm{X}$ & \\
\hline Is resistance to change of each employee examined? & & $\mathrm{X}$ \\
\hline Are employees encourage to constantly strengthen their skills? & $\mathrm{X}$ & \\
\hline Is the firm continuously searching for new creative employees? & $\mathrm{X}$ & \\
\hline Does every employee have their own career plan? & $\mathrm{X}$ & \\
\hline Is the reward system for introducing new idea well known? & & $\mathrm{X}$ \\
\hline
\end{tabular}

Source: own processing

\subsection{Teamwork}

Determinant called "teamwork" looks into ties between employees while working together in teams. Level of objective standards is introduced as part of questionnaire. 
Table 5: Teamwork - part I

\begin{tabular}{|l|c|c|}
\hline Question & Yes & No \\
\hline Are the teams for new projects put together solely on the purpose of new project? & $\mathrm{X}$ & \\
\hline Do people take part in the innovative project on full time basic? & & $\mathrm{X}$ \\
\hline Do you build teams across departmental boundaries? & $\mathrm{X}$ & \\
\hline If yes: is it always positive experience? & $\mathrm{X}$ & \\
\hline Do you use teambuilding to build stronger ties? & & $\mathrm{X}$ \\
\hline $\begin{array}{l}\text { Do every team member have clearly stated objectives in the projects and is he bound by } \\
\text { them? }\end{array}$ & & $\mathrm{X}$ \\
\hline Do you regularly rotate team members in between teams? & & $\mathrm{X}$ \\
\hline Do you have reward system for participation in team projects? & $\mathrm{X}$ \\
\hline
\end{tabular}

Source: own processing

Table 6: Teamwork - part II

\begin{tabular}{|l|c|c|}
\hline Question & Yes & No \\
\hline Is the team located in close distance to each other (geographically)? & $\mathrm{X}$ & \\
\hline $\begin{array}{l}\text { Are the conflicts in the team resolved mainly within the group (opposite to take it to the } \\
\text { higher levels management)? }\end{array}$ & $\mathrm{X}$ & \\
\hline Is the team balance regularly checked through working on the project? & & $\mathrm{X}$ \\
\hline
\end{tabular}

Source: own processing

\subsection{Knowledge management}

Determinant called "knowledge management" investigates the passing of the knowledge and the extent of codified knowledge. external and internal communication of innovation. The extent of feedback is also introduced as part of questionnaire.

Table 7: Knowledge management

\begin{tabular}{|c|c|c|}
\hline Question & Yes & No \\
\hline Is knowledge codified? & $\mathrm{X}$ & \\
\hline Is knowledge captured and transferred though networks? & $\mathrm{X}$ & \\
\hline Is tacit knowledge transferred differently than through personal experience? & & $\mathrm{X}$ \\
\hline Do you find knowledge as most important to its business? & $\mathrm{X}$ & \\
\hline Do you constantly try to acquire knowledge from external sources? & & $\mathrm{X}$ \\
\hline Do you have frameworks to guide the innovation process? & $\mathrm{X}$ & \\
\hline Do you offer creativity training for your employees? & & $\mathrm{X}$ \\
\hline Do employees, who had undergone some training, train other er & $\mathrm{X}$ & \\
\hline
\end{tabular}

Source: own processing

\subsection{Leadership}

Determinant called "leadership" studies the position of leader in the innovation process, his extent of competence. The perception of leader in the company is introduced as part of questionnaire. The questionnaire does not reflect the specific types of leadership or specific roles of people such as idea champions or gatekeepers. 
Table 8: Leadership

\begin{tabular}{|l|c|c|}
\hline Question & Yes & No \\
\hline Does the leader have full responsibility of result of the innovation project? & $\mathrm{X}$ & \\
\hline Is the leader rewarded based on the result of innovation project? & & $\mathrm{X}$ \\
\hline Are leaders recruited from inside sources? & $\mathrm{X}$ & \\
\hline Are leaders encourage to give feedback to their underling? & $\mathrm{X}$ & \\
\hline Are your leaders more like "coaches" then traditional bosses? & & $\mathrm{X}$ \\
\hline Do you support leaders to generate ideas? & $\mathrm{X}$ & \\
\hline Do you support leaders to provide feedback? & $\mathrm{X}$ & \\
\hline Do you support leaders to evaluate? & $\mathrm{X}$ & \\
\hline Do you give leaders freedom for decisions? & $\mathrm{X}$ & \\
\hline Do you distinguish between leaders and managers? & & $\mathrm{X}$ \\
\hline
\end{tabular}

Source: own processing

\subsection{Creativity}

Determinant called "creativity" analyses the approach of company to creativity and its support. The reward for valuable ideas is introduced as part of questionnaire

Table 9: Creativity

\begin{tabular}{|l|c|c|}
\hline Question & Yes & No \\
\hline Does the firm systematically search for new ideas? & $\mathrm{X}$ & \\
\hline Are employees encouraged to express new ideas? & $\mathrm{X}$ & \\
\hline Is failure of new idea accepted? & $\mathrm{X}$ & \\
\hline Is training to improve creativity offered to employees? & & $\mathrm{X}$ \\
\hline Is there any reward for employee whose idea turn out to be valuable? & & $\mathrm{X}$ \\
\hline Is the reward monetary? & $\mathrm{X}$ & \\
\hline Is the reward non-monetary? & $\mathrm{X}$ & \\
\hline
\end{tabular}

Source: own processing

\subsection{Strategy}

Determinant called "strategy" probes the approach to strategy as basics for innovation. The position of strategy for innovation process is introduced as part of questionnaire.

Table 10: Strategy

\begin{tabular}{|l|l|c|}
\hline Question & Yes & No \\
\hline Is the innovation part of strategy? & $\mathrm{X}$ & \\
\hline Is the innovation strategy clearly communicated? & $\mathrm{X}$ & \\
\hline Do you focus on every type of innovation (product, process, marketing or organization)? & $\mathrm{X}$ & \\
\hline Do you have clear parameters for choosing innovation activities you will pursue? & $\mathrm{X}$ & \\
\hline Do you communicate the connection with firms values for every innovation project? & $\mathrm{X}$ & \\
\hline $\begin{array}{l}\text { When you are creating strategy do you use information about your competitors and the } \\
\text { leaders in the market? }\end{array}$ & $\mathrm{X}$ & \\
\hline Is your strategy based on your competencies? & $\mathrm{X}$ & \\
\hline Is your strategy made solely by top management? & & $\mathrm{X}$ \\
\hline Do you consider yourself as innovation leader? & $\mathrm{X}$ & \\
\hline Is the strategy plan formed for period of 3 years at least? & $\mathrm{X}$ & \\
\hline
\end{tabular}

Source: own processing 


\subsection{Continuous improvement}

Determinant called "continuous improvement" tests the approach to continuous improvement in the company. The ability to learn from previous project is introduced as part of questionnaire.

Table 11: Continuous improvement

\begin{tabular}{|c|c|c|}
\hline Question & Yes & No \\
\hline Do you learn from every project? & $\mathrm{X}$ & \\
\hline Do you carry out post-project reviews? & $\mathrm{X}$ & \\
\hline Do you learn from previous unsuccessful innovation activities? & $\mathrm{X}$ & \\
\hline Do you use measurements of innovation success? & $\mathrm{X}$ & \\
\hline Do you compare the results of departments between themselves? & $\mathrm{X}$ & \\
\hline $\begin{array}{l}\text { Are innovation successes and failures reviewed regularly for lesson so it can improve } \\
\text { strategy and process in the future? }\end{array}$ & & $\mathrm{X}$ \\
\hline
\end{tabular}

Source: own processing

\section{Research results}

The aim of the research was to test the questionnaire and its functionality in a company that effectively use innovative processes and which is under constant pressure to improve. Based on result the company is aware of importance of management issues and have stated clear policy in this area. The company is centralized which helps to come up with solution easily and in the shorter period. Vision is created with participation of level of operations management for whom is vision well known. One recommendation would be to communicate the vison to every employee such as operators or manual workers. Constant participation of stakeholders on innovation is part of strategy of the company. The company is attentive of close cooperation with customers since the company is customer oriented. The company collaborates with hospitals and final users of their product so that their needs can be fulfilled. The company has well organized external communication, its web page is easily accessible with clear structure. The journal is published four times a year where new products and ideas are introduced. Internal communication is standardized and clear. Meetings for innovation projects differentiate based on size of the projects. With small project lot of meetings is made informally, for large project rules and standards are introduced especially for frequency of meetings. The feedback is usually not given to all members of the team. In the case of hiring new employee, the focus is on technical skills and education, creativity is questioned only for special positions. Current reward system is under reconstruction and new system will be introduced next year. It will contain monetary and non-monetary rewards for employees. Teamwork is well supported in the company, teams are built across departments, usually formed newly for every project. The expectation of each team member is not objectified, it is left to leader of the team to give guidance. Currently teambuilding is not supported from management. Codification of knowledge exist in the company and it is easily accessible through internal network. The company attempts to establish other ways for transferring tacit knowledge than thought personal experience. Leadership is recognized as important part of managing the company, leaders have a big freedom in decision making, the main important factors which needs to be respected is usually only financial budget. In the innovation projects leaders are usually traditional bosses, in production process they behave more as coaches. Constant search for new ideas is in coherence with company strategy and new ideas within company are welcomed. There is no support for training of creativity of employees. Strategy is fundamental for proper function of company where the company strategy must be in alignment with strategy of whole business group. Innovation is the necessary part of strategy and new ideas are appreciated in every aspect of company`s activities. The company is aware of importance of review of finished innovation project. Objective measurements of successful 
innovation are known before starting the project. Benchmarking of departments success is used as motivation for future work.

\section{Conclusion}

The paper focused on determinants of sustainable innovation management where selected determinants were evaluated by questionnaire. Research suggests that determinants need be managed in close connection with each other mainly because complete separation of one determinant from other is improbable. Innovation is successful when all determinants working well together with result in synergetic effect. It must be point out that focus solely at determinants occurring within the company cannot be recommended. Research is limited by the subjectivity of the corresponding managers and by the subjectivity of the researcher, given that the questionnaire was created based on secondary research and knowledge of the researcher. At the same time, it is necessary to emphasize that the research was made by case study in one company with the leading position in the market of selected sector, so it cannot be said whether the questionnaire can be used in a general scale without any modifications. Further research can be conducted to compare companies with different levels of company management.

\section{References}

[1] AL-BERAIDI, A. and T. RICKARDS, 2003. Creative team climate in an international accounting office: An exploratory study in Saudi Arabia. Managerial Auditing Journal, vol. 18(1), pp. 7-18. ISSN: 0268-6902.

[2] ANDRIOPOULOS, C., 2001. Determinants of organizational creativity: A literature review. Management Decision, vol. 39(10), pp. 834-840.

[3] BLOMBERG, A., T. KALLIO and H. POHJANPAA, 2017. Antecedents of organizational creativity: drivers, barriers or both?. Journal of Innovation Management, vol. 5(1), pp. 78-104.

[4] BOLY, V., L. MOREL, N. G. ASSIELOU and M. CAMARGO, 2014. Evaluating innovative processes in French firms: Methodological proposition for firm innovation capacity evaluation. Research Policy, Elsevier, vol. 43(3), pp. 608-622.

[5] CARNEIRO, A., 2000. How does knowledge management influence innovation and competitiveness? Journal of Knowledge Management, vol. 4(2), pp. 87-98.

[6] COOPER, R. B., 2000. Information Technology Development Creativity: A Case Study of Attempted Radical Change. MIS Quarterly, vol. 24(2), pp. 245-176.

[7] DARROCH, J. and R. MCNAUGHTON, 2002. Examining the link between knowledge management practices and types of innovation. Journal of Intellectual Capital, vol. 3(3), pp. 210-222.

[8] EGAN, T., 2005. Creativity in the context of team diversity: Team leader perspectives. Advances in Developing Human Resources, vol. 7(2), pp. 207-225.

[9] HOEGL, M. and H. GEMUENDEN, 2001. Team work quality and the success of innovative projects: a theoretical concept and empirical evidence. Organization Science, vol. 12(4), pp. 345-449.

[10] KESSEL, M., J. KRATZER and C. SCHULTZ, 2012. Psychological safety, knowledge sharing, and creative performance in healthcare teams. Creativity and Innovation Management, vol. 21(2), pp. 147-157. 
[11] KLEWITZ, J. and E. G. HANSEN, 2014. Sustainability-oriented innovation of SMEs: a systematic review. Journal of Cleaner Production, vol. 65, pp. 57-75.

[12] LOVE, J. H. and S. ROPER, 2015. SME innovation, exporting and growth: a review of existing evidence. International Small Business Journal, vol. 33(1), pp. 28-48.

[13] MUELLER, R. M. and K. THORING, 2012. Design Thinking Vs. Lean Startup: A Comparison of Two User-Driven Innovation Strategies. Proceedings of 2012 International Design Management Research Conference, Boston, pp. 151- 161.

[14] OECD, EUROSTAT, 2005. Oslo Manual: Guidelines for Collecting and Interpreting Innovation Data. [online]. OECD, Oslo. [cit. 6th June 2018]. Available from: http://www.oecd.org/sti/inno/oslomanualguidelinesforcollectingandinterpretinginnovatio ndata3rdedition.htm.

[15] READ, A., 2000. Determinants of Successful Organizational Innovation: A Review of Current Research. Journal of Management Practice, vol 3(1), pp. 95-119.

[16] ROMIJN, H. and M. ALBALADEJO, 2002. Determinants of innovation capability in small electronics and software firms in southeast England. Research Policy, vol. 21(7), pp. 1053-1067.

[17] SCHUMPETER, J. A., 1934. The Theory of Economic Development: An Inquiry into Profits, Capital, Credit, Interests and The Business Cycle. London: Oxford University Press. ISBN: 978-0-674-87990-4.

[18] TANG, H. K., 1998. An Integrative Model of Innovation in Organisations. Technovation, vol. 18(5), pp. 297-309.

[19] THOMPSON, L., 2003. Improving the creativity of organizational work group. Academy of Management Executive, vol. 17(1), pp. 96-109.

[20] TIDD, J. and J. BESSANT, 2009. Managing innovation: integrating technological, market and organizational change. 4th ed., UK, ISBN 978-0-470-99810-6.

[21] TIWANA, A. and E. R. MCLEAN, 2005. Expertise Integration and creativity in information systems development. Journal of Management Information Systems, vol. 22(1), pp. 13-43.

[22] WONG, K. Y. and E. ASPINWALL, 2004. Characterizing knowledge management in the small business environment. Journal of Knowledge Management, vol. 8(3), pp. 4461.

[23] XENOPHON, 474 BC. Hiero. In: Xenophon. Xenophon in Seven Volumes, 7. E. C. Marchant, G. W. Bowersock, Harvard University Press, Cambridge, MA; William Heinemann, Ltd., London. 1925. [online]. [cit. 8th June 2018]. Available from: http://www.perseus.tufts.edu/hopper/text?doc=urn:cts:greekLit:tlg0032.tlg008.perseuseng1:9.

[24] YAMIN, S., A. GUNASEKARAN and F. T. MAVONDA, 1999. Relationship between generic strategies, competitive advantage and organizational performance: an empirical analysis. Technovation, vol. 19(8), pp. 507-518.

[25] ZIEN, K. A. and S. A. BUCKLER, 1997. Dreams to Market: Crafting a Culture of Innovation. The Journal of Product Innovation Management, vol. 14(4), pp. 274-287. 